\title{
Questioned document examination with the use of alternative and complementary non-destructive methods
}

\author{
RAFAŁ CIEŚLA \\ ORCID: 0000-0002-8479-288X \\ Department of Forensic Sciences, Faculty of Law, Administration and Economics \\ University of Wrocław
}

\section{Introduction}

Questioned document examination has for many years occupied a prominent position in widely understood forensic science. Its aim is providing the authority conducting legal proceedings with reliable knowledge about a document, its origin, and confirming or excluding its authenticity. The information contained in a document is determined by an expert, who conducts a comprehensive examination, e.g. handwriting or physico-chemical examination. In practice both are frequently carried out within one expert examination. The philosophy of document examination consists in implementing all available scientific methods and techniques in order to answer the question relevant in each case. ${ }^{1}$

1 D. Ellen, S. Day, Ch. Davies, Scientific Examination of Documents. Methods and Techniques, Boca Raton 2018, pp. 1-6; E. Gruza, M. Goc, J. Moszczyński, Kryminalistyka czyli o współczesnych metodach dowodzenia przestępstw, Warszawa 2020, pp. 443-547. The term "a scientific method" refers to an idealised manner of cognition applicable in all scientific research, characterised by high standards of effectiveness and credibility, constituting the best possible way of discovering the truth and telling it from falsehood and erroneous approach. A scientific method is considered a highly specialised way of 
Experts have always been under pressure to carry out an honest examination based on reliable methods, as its results have a great impact, frequently affecting the knowledge of the authority conducting legal proceedings about a questioned document. ${ }^{2}$

A critical approach to some methods and techniques implemented in forensic science is hardly a new phenomenon, ${ }^{3}$ which results in an effort to improve the quality of document examination and effectiveness of the employed methods as well as to find new and reliable solutions in document identification. 4

describing, explaining and understanding the world, used to arrive at the answers to the posed questions and constructing a non-arbitrary, credible and coherent picture of the world. In less precise terms, a scientific method is simply what scientists do when they solve problems posed by the world and life. In empirical sciences it is a way of solving problems by referring to experiment and reasoning. A. Bronk, "Metoda naukowa", $\mathrm{Na}$ uka 2006, No. 1, p. 51.

2 Forensic Handwriting Examination and Human Factors: The Report of the Expert Working Group for Human Factors in Handwriting Examination, The Working Group on Human Factors in Handwriting Examination, National Institute of Standards and Technology Interagency or Internal Report 8282, U.S. Department of Commerce, February 2020, https://doi.org/10.6028/NIST.IR.8282 (access: 20.04.2020).

3 This is highlighted by D. Ellen, who refers to the work by D.M. Risinger, M.P. Debenaux and M.J. Saks (D.M. Risinger, M.P. Denbeaux, M.J. Saks, "Exorcism of ignorance as a proxy for rational knowledge: The lessons of handwriting identification expertise", University of Pennsylvania Law Review 137, 1989, pp. 731-792), who criticised the discipline of handwriting examination for lack of standards, coherence and external procedures of quality control, identifying it with black magic, D. Ellen, S. Day, Ch. Davies, op. cit. In a similar vein K. Pyrek (Forensic Science Under Siege. The Challenges of Forensic Laboratories and the Medico-Legal Investigation System, Cambridge, MA 2007, pp. 71-78). See also: D. M. Risinger, "Handwriting Identification", [in:] Modern Scientific Evidence: The Law and Science Expert Testimony, eds. D.L. Faigman et al., West 2002; D.M. Risinger, "Appendix: Cases Involving the Reliability of Handwriting Identification Expertise Since the Decision in Daubert", Tulsa Law Review 43, 2007, No. 2, p. 477. D.M. Risinger, "Defining the 'Task at Hand': Non-Science Forensic Science After Kumho Tire Co. v. Carmichael”, Washington and Lee Law Review 57, 2000, No. 3, p. 767; D.M. Risinger, "Navigating Expert Reliability: Are Criminal Standards of Certainty Being Left on the Dock", Albany Law Review 64, 2000, No. 1.

4 For example in Europe the European Network of Forensic Science Institutes (ENFSI) set up special working groups in various disciplines responsible for developing and maintaining standards. In the area of document examination the European Network of Forensic Handwriting Experts (ENFHEX) (handwriting) and the European Document 
Forensic science usually understands a document ${ }^{5}$ as a physical object containing written or printed information. ${ }^{6}$

In today's era of electronic documents increasingly more often we are confronted with access to data contained solely on various carriers, in the Cloud, virtual accounts and coded information available on electronic appliances. Traditional documents are becoming less frequently used, albeit they by no means have entirely disappeared. Growing bureaucracy requires that contracts and other documents are produced in their traditional form. Additionally, most "modern offices" still produce handwritten notes, print emails, photocopy paper documents, all of which may be useful in hearing of evidence. ${ }^{7}$

It is assumed that the information contained in a document is present on two levels. The first is the information seen on the surface of a document in the form of handwriting or print or both. The other is available at a deeper level, providing additional valuable information. Here, at this other level, the expert's role becomes indispensable in acquiring reliable information about, e.g. the author's identity, the author of the signature,

Experts Working Group (EDEWG) (technical examination of documents) were set up. Both ENFSI working groups observe the standards developed for the procedures implemented in document examination (see: www.enfsi.eu). The American Standards for Testing and Materials (ASTM) publishes standards applicable in many disciplines of judicial sciences, including the standards concerning certain aspects of document examination (see: www.astm.org). In Poland there are certification procedures in expert examination carried out in forensic laboratories. A laboratory which adopts certification procedures is obliged to participate in expertise tests carried out by experts appointed by the Polish Certification Centre (see: www.pca.gov.pl), cf. E. Gruza, M. Goc, J. Moszczyński, op. cit., p. 78. See also: Forensic Handwriting Examination and Human Factors: The Report of the Expert Working Group for Human Factors in Handwriting Examination, The Working Group on Human Factors in Handwriting Examination, National Institute of Standards and Technology Interagency or Internal Report 8282, U.S. Department of Commerce, February 2020, https://doi.org/10.6028/NIST.IR.8282 (access: 20.04.2020).

5 Z. Kegel, J. Satko, Przestępstwa przeciwko wiarygodności dokumentów, obrotowi pieniędzmi i papierami wartościowymi. Orzecznictwo Sądu Najwyższego i Sądów Apelacyjnych 1918-2000. Piśmiennictwo, Kraków 2002, pp. 18-22; Z. Kegel, "Pojęcie dokumentu w ustawie, nauce i praktyce prawnokarnej”, Problemy Kryminalistyki 1967, No. 65 , pp. 31-32.

6 R. Cieśla, Technical Examination of Documents. Within the Scope of Polish Evidence Law, Wrocław 2006.

7 D. Ellen, S. Day, Ch. Davies, op. cit., pp. 1-6. 
the source of the text, signature or printout, age of the document (paper, ink), the document's security features, removed or faded text, evidence of interference with the original text and many other factors. ${ }^{8}$

The results of a document expert's work are of utmost importance in determining the facts of the case by the authority conducting legal proceedings. ${ }^{9}$ If documents contain information incriminating a person, their origin becomes the subject of hearing of evidence. If a document is not genuine or contains illegally altered information, the fraud which it constitutes is of essential importance for the prosecution and court.

The Polish Penal Code ${ }^{10}$ in the chapter entitled "Offences against credibility of documents" in art. 270 penalises the so-called substantive falsification (forgery, counterfeiting, use of forged and counterfeited documents as genuine), preparation for falsification of document, filling in a blank forged document, use of a signed document without permission, use of a document at variance with its purpose and to its detriment. The offences of this type also include use of a document authenticating falsehood mentioned in art. 273 and deceitful misleading of a document's issuer determined in art. 272, Polish Penal Code.

Because documents constitute specific evidence accompanying us all our lives, they are vulnerable to forgery. Technical examination of documents ${ }^{11}$ focuses on exposing possible forgery and creating special security features protecting against forgery or counterfeiting. ${ }^{12}$

8 D. Ellen, S. Day, Ch. Davies, op. cit., pp. 1-6; Scientific Examination of Questioned Documents, eds. J.S. Kelly, B.S. Lindblom, Boca Raton 2006, pp. 9-13.

9 Code of Penal Procedure, Act of 6 June 1997 (Dz.U. 1997 No. 89 item 555 with amendments), art. 2 para. 2. Ruling of the Supreme Court of 28 March 2008, III KK 484/07, www.sip.lex.pl (access: 20.04.2020).

10 Penal Code, Act of 6 June 1997 (Dz.U. 1997 No. 88, item 533 with amendments).

11 R. Cieśla, J. Grębowiec-Baffoni, "Problematyka fałszerstw zezwoleń na pobyt we Włoszech”, Człowiek i Dokumenty 2019, 53, pp. 21-32, https://www.pwpw.pl/Czlowiek_i_dokumenty (access: 20.02.2020).

12 M. Owoc, Komputerowe wspomaganie ekspertyzy pismoznawczej, Kraków 1997, p. 4; R. Cieśla, "Security measures in combating document falsifiers", Nowa Kodyfikacja Prawa Karnego (New Criminal Law Codification) 2017, 44, pp. 41-53, DOI: 10.19195/20845065.44.4. 
Examination of documents may consist in, e.g. determining documents' authenticity by examining paper, inks and security features, determining the technique of producing documents, group and individual identification of materials used in producing documents and printing appliances, examination of damaged (e.g. torn, burnt) documents, exposing invisible inscriptions, determining the age of documents, examination of paper and other types of material on which documents are drawn, examination of inks, approval of newly introduced documents. ${ }^{13}$

Examination of documents uses various techniques, while a wide range of this area constitutes a specific challenge for many experts. Continuous development of science and technology provides new methods expanding the area of forensic examination of documents. ${ }^{14}$ A document which constitutes evidence in legal proceedings requires special treatment. It is important that non-damaging methods are used; in certain cases, when their use does not affect the final outcome of the case, the examination methods interfering with the document's structure are admissible. The available methods may not be sufficient in solving all the problems facing an expert and therefore they are being constantly improved. Unfortunately, due to technical reasons, lack of qualified staff, insufficient evidence, inappropriate methodology and examination methods, as well as incorrect interpretation of results from expert opinions are sometimes incomplete, ambiguous or even wrong.

\section{Material, methods and research}

Forensic science has for many years been looking for and implementing non-damaging and reliable methods required by authorities conducting legal proceedings for the needs of document examination. Use of non-damaging methods enables subsequent checking of the obtained results by authorities conducting legal proceedings and the parties in the proceedings

13 L. Koźmiński, Dokument jako ślad kryminalistyczny. Wybrane aspekty, Piła 2020, p. 41.

14 E. Bulska et al., "Oryginał czy kopia - przykład interdyscyplinarnych badań przeprowadzonych w Centrum Nauk Sądowych Uniwersytetu Warszawskiego", [in:] Problematyka dowodu z dokumentu, ed. R. Cieśla, Wrocław 2019, pp. 23-39. 
dissatisfied by and questioning the results of expert opinion. The discussed case is concerned with technical examination of documents with the use of alternative and complementary research methods. The object of the examination was a document — a receipt — with printed and handwritten words. ${ }^{15}$ The aim of the examination was to provide the answer to the question whether the word "sto" (hundred) before the words "pięćdziesiąt trzy" (fifty three) and the figure " 1 " before the figures " 53 " on the receipt No. 2383... were written with the same ink as the remaining entries on the receipt. The examination material was the receipt, blue in colour, of the size $138 \times 49 \mathrm{~mm}$ whose spaces were filled in ink, possibly with a ball pen. The receipt had the number 2383 ..., a stamp in the right lower corner which said: * URZĄD MIEJSKI * KASA nr 1 (* MUNICIPAL OFFICE * CASHIER'S DESK No. 1) and illegible initials. To perform the qualitative test of the ink and of the homogeneity of paper, the document was examined with the use of a video spectral comparator VSC 2000/HR, ${ }^{16}$ which enables examination of a questioned document in various types of light and at various magnifications. The document was examined in the range from near infrared to visible light to ultraviolet and in spot light. In these conditions and with the use of a filter cutting off the falling light, possible fluorescence of ink (or its residues on paper) may be seen.

\begin{tabular}{|c|c|}
\hline 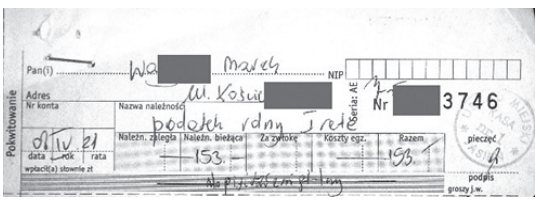 & 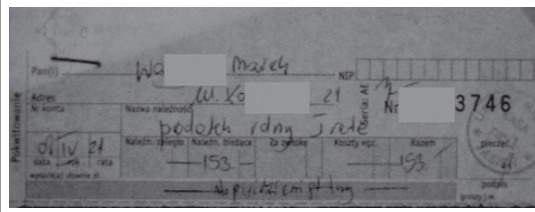 \\
\hline $\begin{array}{l}\text { Fig. 1. Examined document in white light } \\
\text { enriched with infrared radiation. }\end{array}$ & $\begin{array}{l}\text { Fig. 2. Examined document in long-wave } \\
(365 \mathrm{~mm}) \text { ultraviolet light. }\end{array}$ \\
\hline
\end{tabular}

15 Polish District Court in Żary, Criminal Division, case II K 335/09.

16 www.fosterfreeman.com (access: 10.03.2020); G.M. Mokrzycki, "Advances in Document Examination: The Video Spectral Comparator", Forensic Science Communications 1, 1999, No. 3, https://archives.fbi.gov/archives/about-us/lab/forensic-science-communications/fsc/oct1999/mokrzyck.htm (access: 10.09.2019). 


\begin{tabular}{|c|c|}
\hline a d & 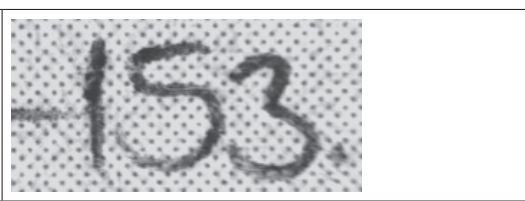 \\
\hline $\begin{array}{l}\text { Fig. 3. Fragment of questioned entry } \\
\text { "1" in the examined document in space } \\
\text { "Należn." ("Amount due") in white } \\
\text { light enriched with infrared radiation at } \\
\text { maximum magnification of VSC } 2000 / \mathrm{HR} \text {. }\end{array}$ & $\begin{array}{l}\text { Fig. 4. Fragment of questioned entry } \\
\text { "1" in the examined document in space } \\
\text { "Należn." ("Amount due") in long-wave } \\
\text { (365 mm) ultraviolet light at maximum } \\
\text { magnification of VSC } 2000 / \mathrm{HR} \text {. }\end{array}$ \\
\hline
\end{tabular}

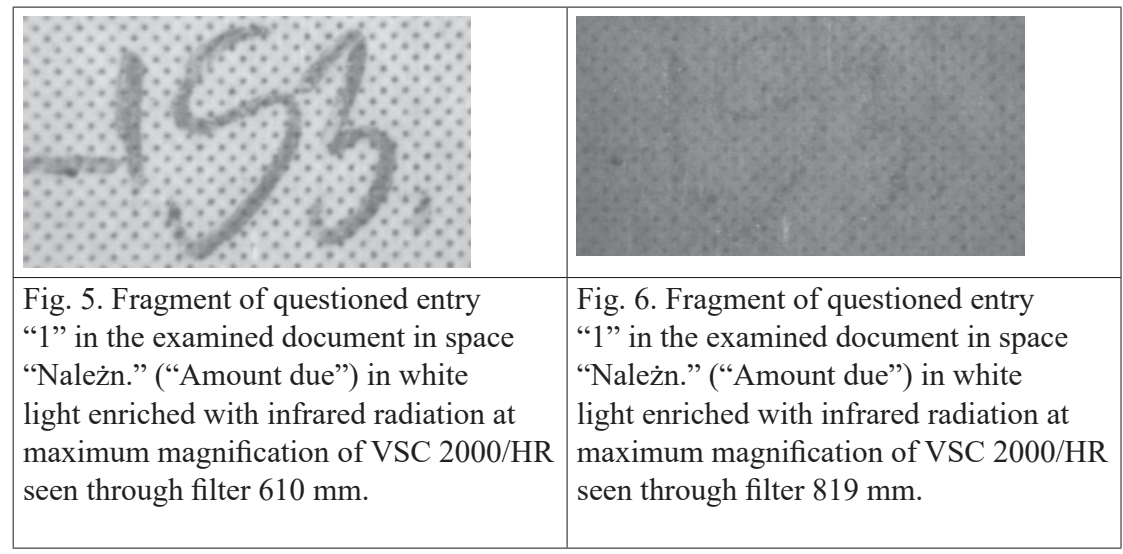

\begin{tabular}{|l|l|}
\hline & 0 \\
\hdashline
\end{tabular}




\begin{tabular}{|l|l|}
\hline & \\
\hline $\begin{array}{l}\text { Fig. 9. Fragment of questioned entry } \\
\text { "1" in the examined document in space } \\
\text { "Razem" ("Total amount") in white } \\
\text { light enriched with infrared radiation at } \\
\text { maximum magnification of VSC 2000/HR } \\
\text { seen through filter 610 mm. }\end{array}$ & $\begin{array}{l}\text { Fig. 10. Fragment of questioned entry } \\
\text { "1" in the examined document in space } \\
\text { "Razem" ("Total amount") in white } \\
\text { light enriched with infrared radiation at } \\
\text { maximum magnification of VSC 2000/HR } \\
\text { seen through filter } 819 \text { nm. }\end{array}$ \\
\hline
\end{tabular}

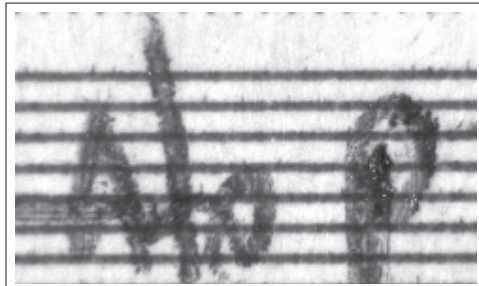

Fig. 11. Questioned entry "sto" in the examined document in white light enriched with infrared radiation at maximum magnification of VSC 2000/HR.

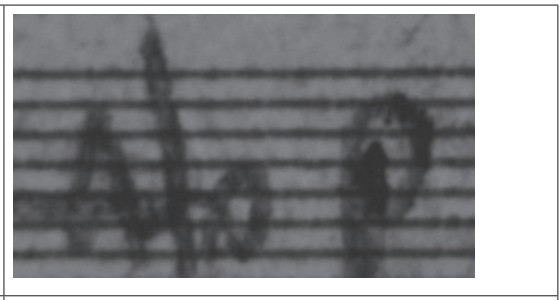

Fig. 12. Fragment of questioned entry "sto" in the examined document in long-wave $(365 \mathrm{~mm})$ ultraviolet light at maximum magnification of VSC 2000/HR.

\begin{tabular}{|l|l|}
\hline & \\
\hline $\begin{array}{l}\text { Fig. 13. Questioned entry "sto" in the } \\
\text { examined document in white light } \\
\text { enriched with infrared radiation at } \\
\text { maximum magnification of VSC 2000/HR } \\
\text { seen through a filter of } 610 \mathrm{~mm} .\end{array}$ & $\begin{array}{l}\text { Fig. 14. Questioned entry "sto" in the } \\
\text { examined document in monochromatic } \\
\text { (630/740 mm) spot light at maximum } \\
\text { magnification of VSC 2000/HR seen } \\
\text { through a filter of 780 mm. }\end{array}$ \\
\hline
\end{tabular}


The analysis of the obtained images in figures 15, 16, and 17 showed that that the line blocking the word entry "sto" overlaps the first letter of the word "sto" and was thus probably drawn after the word was written. Therefore optical homogeneity of the blocking line was examined (Fig. $15,16,17)$.

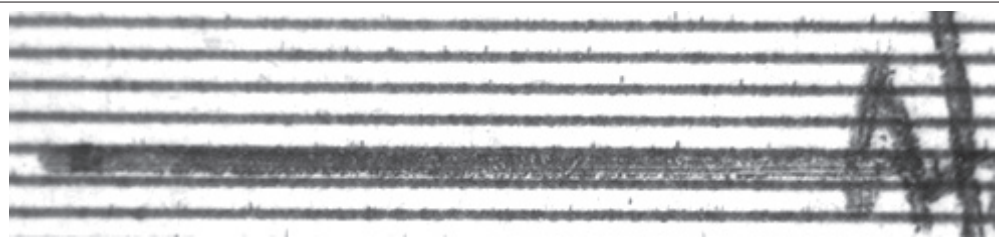

Fig. 15. Horizontal blocking line before the entry "sto" in the examined document in white light enriched with infrared radiation at maximum magnification of VSC 2000/HR.

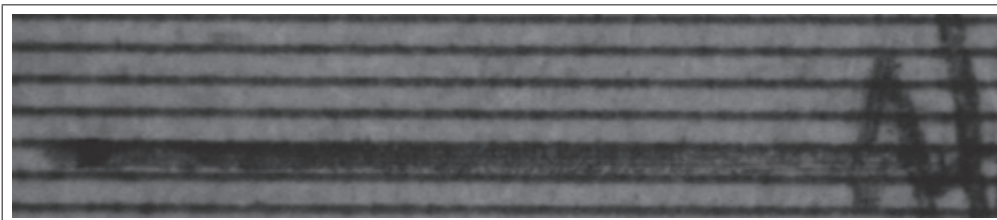

Fig. 16. Horizontal blocking line before the entry "sto" in the examined document in long-wave (365 mm) ultraviolet light at maximum magnification of VSC 2000/HR.

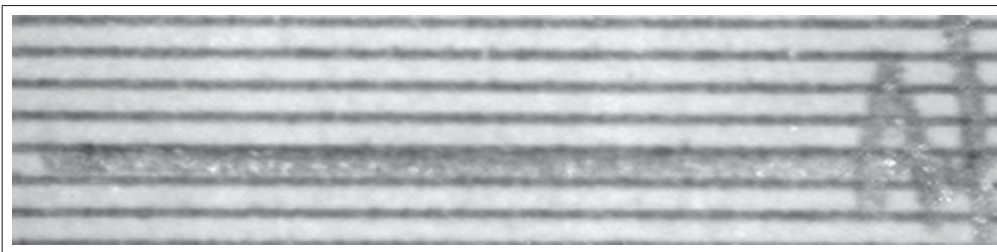

Fig. 17. Horizontal blocking line before the entry "sto" in the examined document in white spot light enriched with infrared radiation $(<750 \mathrm{~nm})$ seen through a cut-off filter of $780 \mathrm{~mm}$. 
Various types of electronic spectra, such as absorption, reflection and transmission spectra, are used for comparative purposes. The video spectral comparator 2000/HR provides such spectra of lines written in ink. ${ }^{17}$ Additionally, it provides fluorescence spectra of ink. The spectra are obtained when ink is illuminated with monochromatic light of an appropriate wavelength (inducing fluorescence) and observed through a filter cutting off the light inducing fluorescence. Twenty measurements were made for one entry (in different places) and averaged. ${ }^{18}$ As both questioned and unquestioned entries were written in a similar colour, spectra were also made for unquestioned entries and averaged (Fig. 18). The results of measurements revealed differences in spectra. Then the averaged reflection spectrum of ink of the questioned entry "1" was subtracted from the averaged reflection spectrum of ink of the unquestioned entry " 5 ". As the background for the figures was an arrangement of small blue dots and when taking the reflection spectra it was practically impossible to avoid a dot, subsequent spectra were made for comparison. The reflection spectrum of ink of the dot in the background was subtracted from the reflection spectrum of ink of the questioned entry " 1 " in the space "Należn." in the examined document. The same subtraction procedure was repeated for ink of entry " 5 " for comparison.

As the questioned and unquestioned entries were in a similar colour, to compare the inks respective reflection spectra of inks from the examined document were presented in a graph (Fig. 18).

The positions of maximum values for reflection spectra seen in the illustration are practically the same, which may prove that there is no difference in colour between the compared inks. To emphasise possible differences, derivatives of spectra on wavelength were obtained. The derivative crosses the $\mathrm{x}$-axis at the point corresponding to the maximum of the curve (Fig. 19).

17 R. Cieśla, "The significance of non-invasive methods of document examination in evidentiary proceedings", Nowa Kodyfikacja Prawa Karnego (New Criminal Law Codification) 2019, 51, pp. 65-79; DOI: 10.19195/2084-5065.51.5.

18 G. Rusek, R. Cieśla, “Zmiany właściwości spektroskopowych jako efekt fotodegradacji barwników", [in:] Dokumenty a prawo: prawne oraz praktyczne aspekty korzystania z dokumentów i e-dokumentów, eds. M. Tomaszewska-Michalak, T. Tomaszewski, Warszawa 2015, pp. 21-34. 


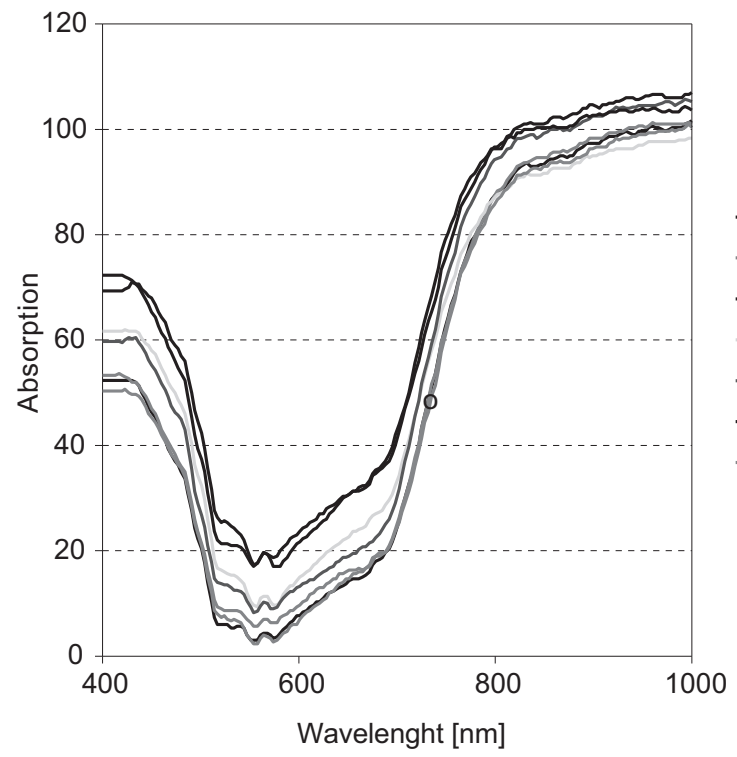

— Ink of 1 in Space "Należn."

— Ink of 5 in Space "Należn."

— Ink of 1 in Space "Razem"

- Ink of 5 in Space "Razem"

— Ink of entry "sto"

— Ink of blocking line

_ Ink of entry "pięćdziesiąt"

Fig. 18. Averaged reflection spectra of inks on the questioned document.

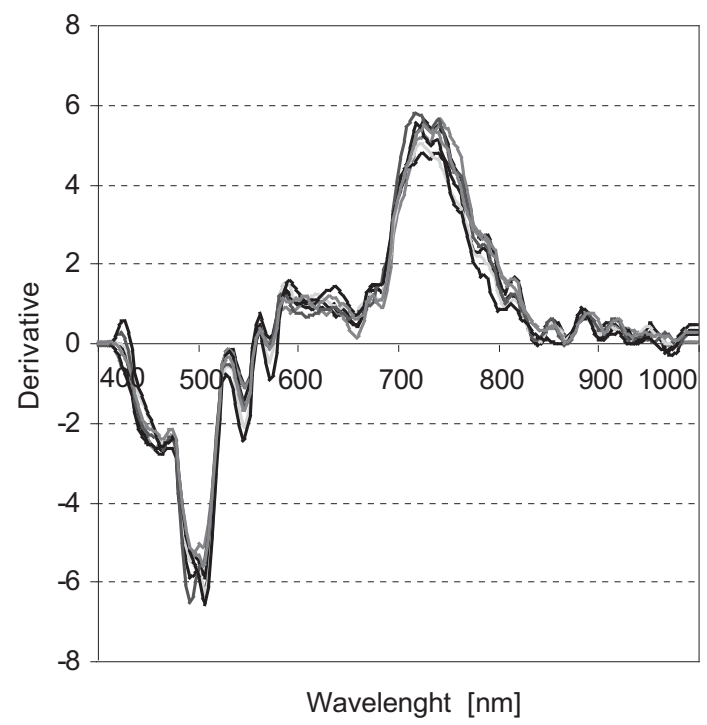

— Ink of 1 in Space "Należn."

— Ink of 5 in Space "Należn."

— Ink of 1 in Space "Razem"

_ Ink of 5 in Space "Razem"

- Ink of entry "sto"

— Ink of blocking line

— Ink of entry "pięćdziesiąt"

Fig. 19. First derivatives of averaged reflection spectra of white light enriched with infrared radiation of inks on the examined document. 
The positions of maximum values of spectra practically do not differ, which proves that the colours were similar. To compare the position of spectral inflexion more precisely the range for the maximum was extended, i.e. at the point of crossing the $\mathrm{x}$-axis (wavelength) by the derivative (Fig. 20).

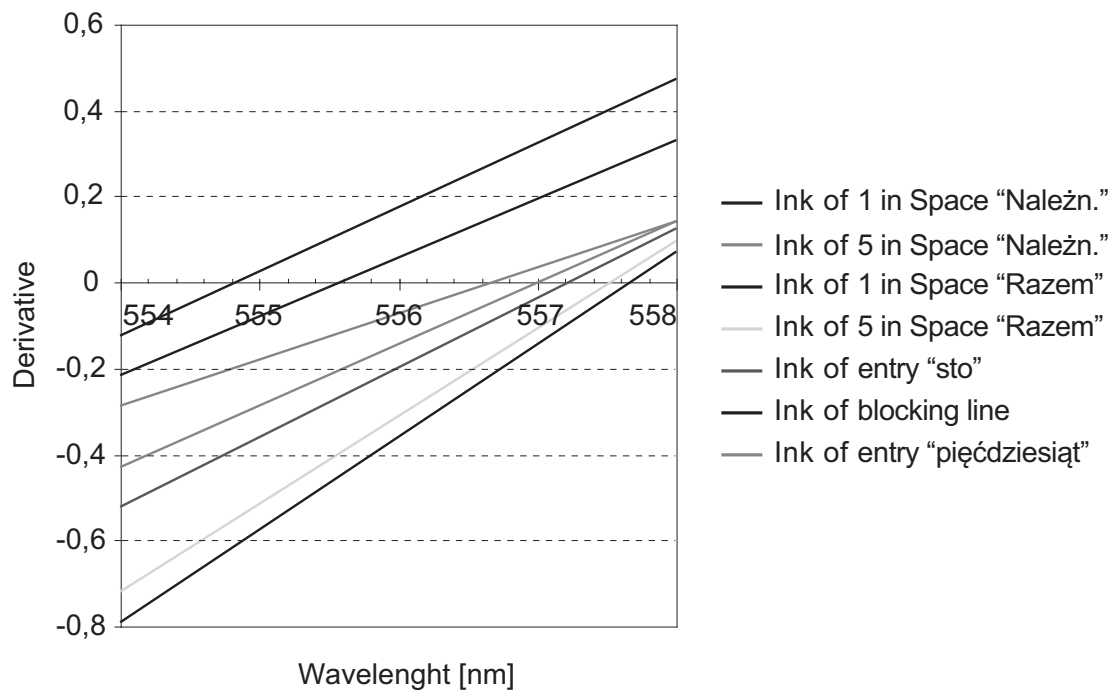

Fig. 20. "Extended" range of scale at the point of crossing the $\mathrm{x}$-axis by the derivatives of averaged reflection spectra of inks on the examined document.

As the positions of maximum values in the case of reflection spectra in the comparison of spectra of inks on the document practically displayed no differences, the mean value $\{\boldsymbol{x}\}$ of the position of spectral maximum was calculated according to the formula:

$\{1\}$

$$
\bar{x}=\frac{\sum_{i=1}^{n} x_{i}}{n}
$$

where: $\boldsymbol{x}_{\boldsymbol{i}}=$ consecutive maximum of absorption

average deviation $\{\boldsymbol{d}\}$ of maximum of absorption was calculated according to the formula: 


\section{$\{2\}$}

$d=\frac{1}{n} \sum_{i-1}^{n}\left(x_{i}-\bar{x}\right)$

variance $\left\{\boldsymbol{s}^{2}\right\}$ of maximum of absorption was calculated according to the formula:

$\{3\}$

$$
s^{2}=\frac{\sum_{i=1}^{n}\left(x_{i}-\bar{x}\right)^{2}}{n-1}
$$

and mean standard deviation $\left\{\boldsymbol{s}_{\boldsymbol{r}}\right\}$ of maximum of absorption was calculated according to the formula:

$$
s_{r}=\sqrt{\frac{\sum_{i=1}^{n}\left(x_{i}=\bar{x}\right)^{2}}{n-1}}
$$

The obtained results are presented in Table 1

Table 1. Estimation of error

\begin{tabular}{|l|c|c|c|c|c|}
\hline Description of sample & $\begin{array}{c}\text { Maximum of } \\
\text { absorption } \\
{[\mathrm{nm}]}\end{array}$ & $\begin{array}{c}\text { Mean } \\
\text { value } \\
\boldsymbol{x}\end{array}$ & $\begin{array}{c}\text { Average } \\
\text { deviation } \\
d\end{array}$ & $\begin{array}{c}\text { Variance } \\
s^{2}\end{array}$ & $\begin{array}{c}\text { Mean } \\
\text { standard } \\
\text { deviation }\end{array}$ \\
\hline " $\boldsymbol{l}$ " in space "Należn." & 555.6 & & & & \\
\hline "5" in space "Należn." & 556.6 & & & & \\
\cline { 1 - 2 } " $\boldsymbol{I}$ " in space "Razem" & 554.8 & \multirow{2}{*}{556.47} & 0.84 & 1.13 & 1.06 \\
\cline { 1 - 2 } "5" in space "Razem" & 557.6 & & & & \\
\hline entry "sto" & 557.2 & & & & \\
\hline entry "pięćdziesią" & 557 & & & &
\end{tabular}

Spectroscopy in visible and ultraviolet range of the spectrum, i.e. electronic spectra, mainly carries information about the colour composition of ink. Oscillation spectra, which include spectroscopy in infrared and Raman, carry information about structural elements of ink. The inks on the document were examined with a Raman spectral comparator FORAM 685-2. ${ }^{19}$ The apparatus' laser causes ink to emit radiation. Averaging the measurements means that for each spectrum a minimum of 20 measurements of one entry were made (in its different places) (Fig. 21, 22).

19 R. Cieśla, Technical Examination of Documents, pp. 146-147. See also: www. fosterfreeman.com (access: 10.03.2020).

Nowa Kodyfikacja Prawa Karnego 57, 2020

(C) for this edition by CNS 


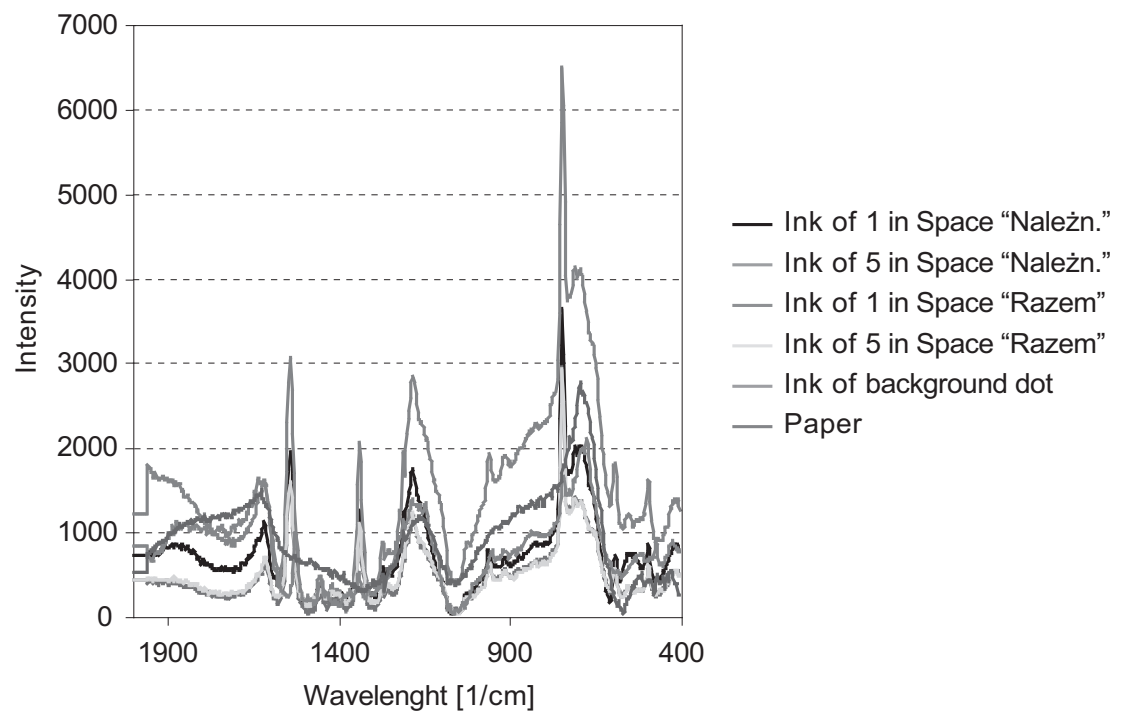

Fig. 21. Comparison of averaged Raman spectra of entries' ink, dots in the background and paper of the examined document caused by the laser's light of $685 \mathrm{~nm}$.

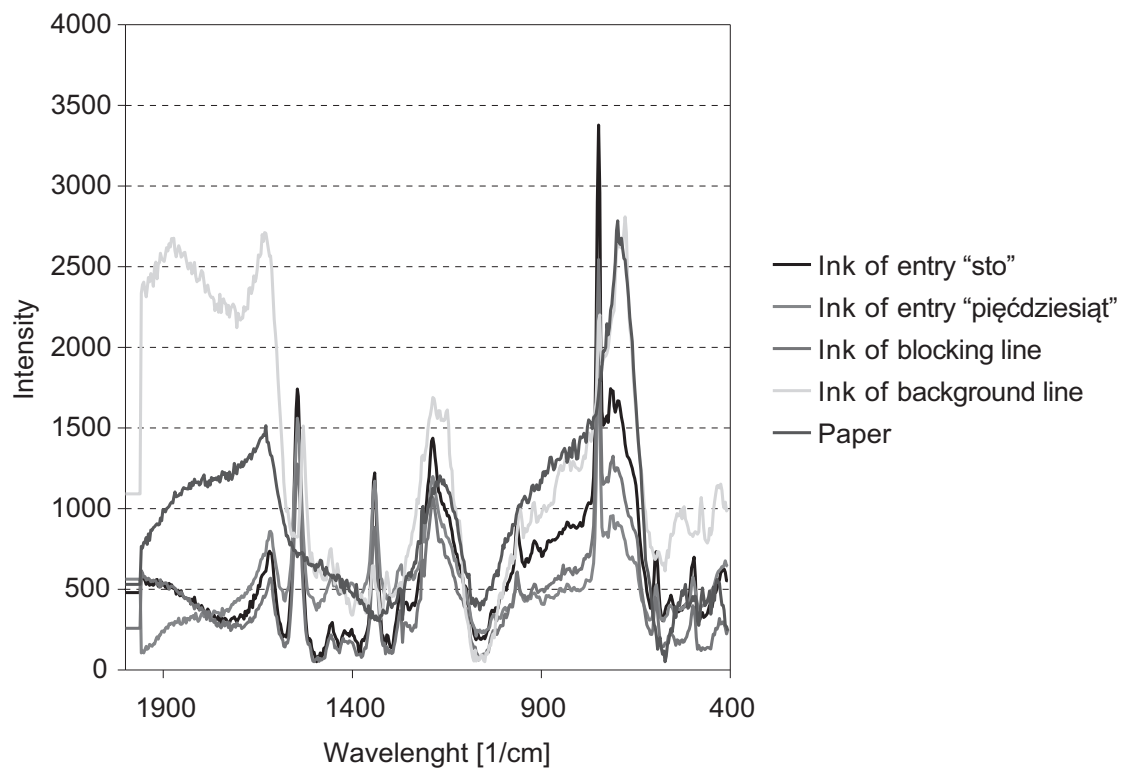

Fig. 22. Comparison of averaged Raman spectra of entries' ink, blocking line, lines in the background and paper of the examined document caused by the laser's light of $685 \mathrm{~nm}$.

Nowa Kodyfikacja Prawa Karnego 57, 2020

(C) for this edition by CNS 


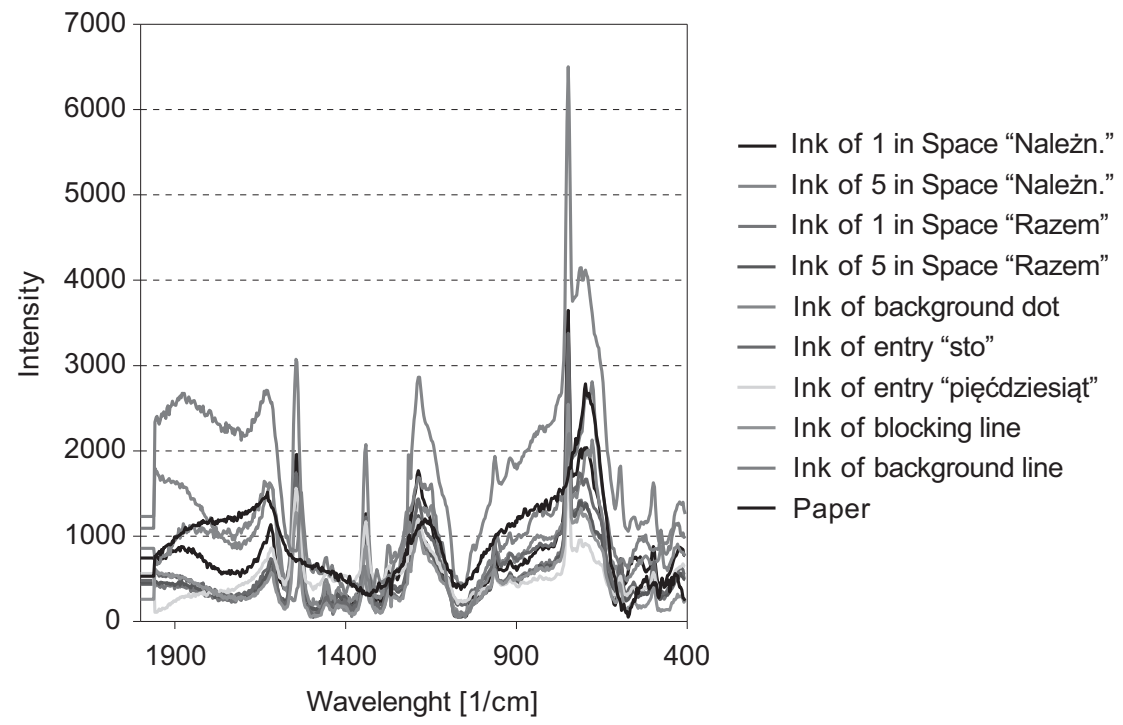

Fig. 23. Comparison of averaged Raman spectra of inks and paper of the examined document caused by the laser's light of $685 \mathrm{~nm}$.

Similarly as in the case of reflection spectra of inks, the error of position of individual peaks may be estimated according to the same formulas. The three most intensive peaks were selected for estimation of error (Table 2).

Table 2. Position of peaks: estimation of error

\begin{tabular}{|c|c|c|c|c|c|}
\hline Description of sample & $\begin{array}{c}\text { peak } \\
{[1 / \mathrm{cm}]}\end{array}$ & $\begin{array}{c}\text { Mean } \\
\text { value } \\
x\end{array}$ & $\begin{array}{c}\text { Average } \\
\text { deviation } \\
D\end{array}$ & $\underset{s^{2}}{\text { Variance }}$ & $\begin{array}{c}\text { Mean } \\
\text { standard } \\
\text { deviation }\end{array}$ \\
\hline "1" in space "Należn." & 747 & \multirow{6}{*}{747} & \multirow{6}{*}{0} & \multirow{6}{*}{0} & \multirow{6}{*}{0} \\
\hline "5" in space "Należn." & 747 & & & & \\
\hline "1" in space "Razem" & 747 & & & & \\
\hline "5" in space "Razem" & 747 & & & & \\
\hline entry "sto" & 747 & & & & \\
\hline entry "pięćdziesiąt" & 747 & & & & \\
\hline
\end{tabular}




\begin{tabular}{|c|c|c|c|c|c|}
\hline Description of sample & $\begin{array}{c}\text { peak } \\
{[1 / \mathrm{cm}]}\end{array}$ & $\begin{array}{c}\text { Mean } \\
\text { value } \\
x\end{array}$ & $\begin{array}{c}\text { Average } \\
\text { deviation } \\
D\end{array}$ & $\begin{array}{c}\text { Variance } \\
s^{2}\end{array}$ & $\begin{array}{c}\text { Mean } \\
\text { standard } \\
\text { deviation }\end{array}$ \\
\hline "1" in space "Należn." & 1339 & \multirow{6}{*}{1338.3} & \multirow{6}{*}{0.89} & \multirow{6}{*}{1.07} & \multirow{6}{*}{1.03} \\
\hline "5" in space "Należn." & 1339 & & & & \\
\hline "1" in space "Razem" & 1339 & & & & \\
\hline "5" in space "Razem" & 1339 & & & & \\
\hline entry "sto" & 1337 & & & & \\
\hline entry "pięćdziesiąt" & 1337 & & & & \\
\hline "1" in space "Należn." & 1543 & \multirow{6}{*}{1543.7} & \multirow{6}{*}{0.44} & \multirow{6}{*}{0.27} & \multirow{6}{*}{0.52} \\
\hline "5" in space "Należn." & 1544 & & & & \\
\hline "1" in space "Razem" & 1544 & & & & \\
\hline "5" in space "Razem" & 1544 & & & & \\
\hline entry "sto" & 1543 & & & & \\
\hline entry "pięćdziesiąt" & 1544 & & & & \\
\hline
\end{tabular}

\section{Summary}

Analysis of electronic spectra of questioned entries ("1" and "sto") and comparative entries ("5" and "pięćdziesiąt") obtained with the use of VSC 2000/HR (Visual Spectral Comparator) revealed that all the examined entries were made in ink of an identical colour, which is confirmed by the analysis of errors (Table 1); the obtained value of mean standard deviation of the position of the maximum values of absorption of reflection spectra $(1.03 \mathrm{~nm})$ reveals that the differences in positions of maximum values are negligible.

The analysis of oscillation (Raman) spectra of questioned entries ("1" and "sto") and comparative entries ("5" and "pięćdziesiąt") obtained with the use of Raman Spectral Comparator FORAM 685-2 revealed that all the examined entries were probably written in an ink belonging to the same group, with the same structure of components producing a characteristic Raman spectrum. This was confirmed by the analysis of errors (Table 2), the obtained values of mean standard deviation of the position of the three most intensive (characteristic) peaks: $0 \mathrm{~cm}^{-1}, 1.03 \mathrm{~cm}^{-1}$ and 
$0.52 \mathrm{~cm}^{-1}$, which proves that the differences in the positions of peaks are negligible. Thus it should be assumed with a great degree of probability that the word "sto" written before the words "pięćdziesiąt trzy" and figure " 1 " before figures " 53 " in spaces "Należn." and "Razem" were written in the same ink as the word "pięćdziesiąt" and figure " 5 " in spaces "Należn." and "Razem".

The analysis of images (Fig. 15, 16, 17) did not reveal significant discontinuity of the blocking line before the questioned word "sto". At the same time the analysis of the obtained images (Fig. 11, 12, 13, 14) revealed that the line blocking the word "sto" overlaps the first letter of the word "sto" and was thus drawn after the word was written, which additionally confirms the conclusion above.

Because the analysis of electronic spectra proved the similarity of colour and the analysis of oscillation spectra proved the similarity of structural elements, further examination with the use of thin-layer chromatography was abandoned, as it would have necessitated damaging the document. At the same time the amount of material that could be obtained for the damaging examination in the case of figure " 1 " would not have been sufficient as the methodology of the examination requires cutting out between several and a dozen $1 \mathrm{~mm}$ fragments from the line written in the ink in question.

\section{Bibliography}

Bronk A., "Metoda naukowa", Nauka 2006, No. 1.

Bulska E., Donten M., Łabędź O., Tomaszewski T., “Oryginał czy kopia — przykład interdyscyplinarnych badań przeprowadzonych w Centrum Nauk Sądowych Uniwersytetu Warszawskiego", [in:] Problematyka dowodu z dokumentu, ed. R. Cieśla, Wrocław 2019, pp. 23-39.

Cieśla R., "Security measures in combating document falsifiers", Nowa Kodyfikacja Prawa Karnego (New Criminal Law Codification) 2017, 44, pp. 41-53, DOI: 10.19195/20845065.44.4.

Cieśla R., "The significance of non-invasive methods of document examination in evidentiary proceedings", Nowa Kodyfikacja Prawa Karnego (New Criminal Law Codification) 2019, 51, pp. 65-79; 10.19195/2084-5065.51.5.

Cieśla R., Technical Examination of Documents. Within the Scope of Polish Evidence Law, Wrocław 2006. 
Cieśla R., Grębowiec-Baffoni J., "Problematyka fałszerstw zezwoleń na pobyt we Włoszech", Człowiek i Dokumenty 2019, 53, pp. 21-32, https:/www.pwpw.pl/Czlowiek_i_dokumenty (access: 20.02.2020).

Code of Penal Procedure, Act of 6 June 1997 (Dz.U. 1997 No. 89 item 555 with amendments), art.2 para.2.

Ellen D., Day S., Davies Ch., Scientific Examination of Documents. Methods and Techniques, Boca Raton 2018.

Forensic Handwriting Examination and Human Factors: The Report of the Expert Working Group for Human Factors in Handwriting Examination, The Working Group on Human Factors in Handwriting Examination, National Institute of Standards and Technology Interagency or Internal Report 8282, U.S. Department of Commerce, February 2020, https://doi.org/10.6028/NIST.IR.8282 (access: 20.04.2020).

Gruza E., Goc M., Moszczyński J., Kryminalistyka czyli o wspótczesnych metodach dowodzenia przestepstw, Warszawa 2020.

Kegel Z., "Pojęcie dokumentu w ustawie, nauce i praktyce prawnokarnej”, Problemy Kryminalistyki 1967, No. 65, pp. 31-32.

Kegel Z., Satko J., Przestęstwa przeciwko wiarygodności dokumentów, obrotowi pieniędzmi i papierami wartościowymi. Orzecznictwo Sądu Najwyższego i Sądów Apelacyjnych 1918-2000. Piśmiennictwo, Kraków 2002.

Koźmiński L., Dokument jako ślad kryminalistyczny. Wybrane aspekty, Piła 2010.

Mokrzycki G.M., "Advances in Document Examination: The Video Spectral Comparator", Forensic Science Communications 1, 1999, No. 3, https://archives.fbi.gov/ archives/about-us/lab/forensic-science-communications/fsc/oct1999/mokrzyck.htm (access: 10.09.2019).

Owoc M., Komputerowe wspomaganie ekspertyzy pismoznawczej, Kraków 1997.

Penal Code, Act of 6 June 1997, (Dz.U. 1997 No. 88, item 533 with amendments).

Polish District Court in Żary, Criminal Division, case II K 335/09.

Pyrek K., Forensic Science Under Siege. The Challenges of Forensic Laboratories and the Medico-Legal Investigation System, Cambridge, MA 2007, pp. 71-78.

Risinger D.M., "Appendix: Cases Involving the Reliability of Handwriting Identification Expertise Since the Decision in Daubert", Tulsa Law Review 43, 2007, No. 2, p. 477.

Risinger D.M., "Defining the 'Task at Hand': Non-Science Forensic Science After Kumho Tire Co. v. Carmichael", Washington and Lee Law Review 57, 2000, No. 3, p. 767.

Risinger D.M., "Handwriting Identification”, [in:] Modern Scientific Evidence: The Law and Science Expert Testimony, eds. D.L. Faigman et al., West 2002.

Risinger D.M., "Navigating Expert Reliability: Are Criminal Standards of Certainty Being Left on the Dock", Albany Law Review 64, 2000, No. 1.

Risinger D.M., Denbeaux M.P., Saks M.J., "Exorcism of ignorance as a proxy for rational knowledge: The lessons of handwriting identification expertise", University of Pennsylvania Law Review 137, 1989, pp. 731-792.

Rusek G., Cieśla R., "Zmiany właściwości spektroskopowych jako efekt fotodegradacji barwników", [in:] Dokumenty a prawo: prawne oraz praktyczne aspekty korzysta- 
nia z dokumentów i e-dokumentów, eds. M. Tomaszewska-Michalak, T. Tomaszewski, Warszawa 2015, pp. 21-34.

Scientific Examination of Questioned Documents, eds. J.S. Kelly, B.S. Lindblom, Boca Raton 2006, pp. 9-13.

\section{Internet sources}

Www.astm.org (access: 10.03.2020).

www.enfsi.eu (access: 10.03.2020).

www.fosterfreeman.com (access: 10.03.2020).

www.pca.gov.pl (access: 10.03.2020).

www.sip.lex.pl (access: 10.03.2020).

\section{Summary}

Questioned document examination occupies an important position in forensic science. Its purpose is to provide the authority conducting legal proceedings with reliable knowledge confirming or excluding authenticity of a document, therefore every effort should be made to use relevant and legally admissible examination methods. For many years reliable non-destructive methods have been developed, whose use in expert examination will enable subsequent control both by the authority conducting legal proceedings and other parties in the proceedings. This article proposes the use of alternative non-destructive methods in examination of documents.

Keywords: questioned document examination, non-invasive methods, ink examination, Video Spectral Comparator, VSC2000/HR, Raman Spectral Comparator, FORAM 685-2. 